УДК [378.015.311:373.3.011.3-051]:364-322

DOI: $\underline{10.35619 / \text { iiu.v2i11.253 }}$

Гринькова Надія

кандидат педагогічних наук, доцент, доцент кафедри теорії і методики виховання Рівненського державного гуманітарного університету, м. Рівне, Україна ORCID: 0000-0002-5774-8699, e-mail: nadiia.hrynkova@rshu.edu.ua

Стельмашук Жанна кандидат педагогічних наук, доцент кафедри теорії і методики виховання Рівненського державного гуманітарного університету,

м. Рівне, Україна

ORCID: 0000-0003-2368-4209, e-mail: zhanna.stelmashuk@rshu.edu.ua

Ваколюк Аліна

кандидат педагогічних наук, доцент кафедри теорії і методики виховання Рівненського державного гуманітарного університету, м. Рівне, Україна

ORCID: 0000-0003-1545-0867, e-mail:alinavakoliuk88@gmail.com

\title{
РОЛЬ ВОЛОНТЕРСЬКОЇ ДІЯЛЬНОСТІ У ФОРМУВАННІ ОСОБИСТОСТІ МАЙБУТНЬОГО ВЧИТЕЛЯ ПОЧАТКОВОЇ ШКОЛИ
}

Анотація. У статті обгрунтовано роль волонтерської діяльності у становленні особистості майбутнього педагога початкової школи. Здійснений аналіз нормативноправових документів 3 питань освіти дав змогу констатувати, що вчителем повинна бути особа з високими моральними якостями, яка має відповідну педагогічну освіту, належний рівень професійної підготовки, забезпечує результативність та якість своєї роботи. 3'ясовано, що волонтерська діяльність є способом підтримки, піклування, надання допомоги тим, хто іiі потребує. Схарактеризовано досвід діяльності студентського волонтерського центру «Від серця до серця», який засвідчив значний потенціал волонтерської діяльності як одного із чинників формування особистості майбутнього педагога Нової української школи. Практично доведено, що благодійна діяльність має значний потенціал для розвитку базових моральних цінностей особистості, соціальної компетентності студентів педагогічного факультету (навичок взаєморозуміння, співпраці, поваги, толерантності, емпатії, відповідальності, уміння працювати в групах); сприяе розвитку лідерських якостей, творчого потенціалу, критичного мислення; сприяє удосконаленню педагогічної майстерності, розвитку стресостійкості та емоційного інтелекту майбутніх учителів початкової школи.

(C) Гринькова Н., Стельмашук Ж.,

Ваколюк А., 2020 
Констатовано, що волонтерська діяльність є одним із головних напрямів діяльності закладів вищої освіти і відіграє важливу роль у підготовці майбутнього вчителя початкової школи, його саморозвитку та самовдосконалення.

Ключові слова: волонтерство, волонтерська діяльність, благодійництво, особистість майбутнього вчителя початкової школи, професійна компетентність, Нова українська школа, студентський волонтерський центр «Від серця до серця».

Постановка проблеми. Одним із важливих завдань сьогодення, як зазначено в Законі України «Про вищу освіту», $є$ «формування особистості шляхом патріотичного, правового, екологічного виховання, утвердження в учасників освітнього процесу моральних цінностей, соціальної активності, громадянської позиції та відповідальності, здорового способу життя, вміння вільно мислити та самоорганізовуватися в сучасних умовах» (2017). Водночас місія сучасного вчителя початкової школи розглядається в контексті європейського професіоналізму із збереженням кращих ментальних українських характеристик, європейського виміру педагогічних якостей.

Наприклад, у програмі «Нова українська школа» у поступі до цінностей» зазначено, що «ключовим внутрішнім викликом духовної безпеки нації виступає національна самоідентифікація, яка втілюється у почуттях-цінностях - «Я - Українець» - «Ми Українці». У свою чергу кожна «особистість має прийняти історичну естафету вищих духовних надбань нації, жити і діяти на їх основі та примножувати їх з урахуванням викликів теперішнього часу». Саме тому в наш час важливою є активізація зусиль 3 підвищення духовного рівня української молоді, формування у неї стійкої системи глибоких морально-духовних цінностей...» (2018).

Одним із чинників розвитку особистісного потенціалу студентської молоді, іiі ініціативності, правової культури, громадянської позиції $\epsilon$ волонтерська діяльність. Різноманітність напрямів, форм і методів благодійної роботи відкриває значні можливості для розвитку соціальної ініціативності, критичного мислення майбутніх учителів початкової школи. Волонтерський рух надає можливість молодим людям вчитися та реалізувати себе шляхом надання допомоги як окремій людині, так і суспільству в цілому. Особливе значення волонтерська діяльність відіграє у професійному становленні майбутніх педагогів як носіїв морально-етичних та суспільно-політичних цінностей, оскільки уможливлює формування у них зазначених вище якостей та умінь через активне залучення до реалізації конкретних добровільних справ.

Аналіз останніх досліджень 3 проблеми. Проведений аналіз наукових джерел дає підстави для висновку про різноаспектність актуалізованої проблеми. Зокрема, характеристику головних вимог до сучасного вчителя в контексті його готовності до ефективної професійної діяльності із урахуванням компетентнісного підходу здійснили Л. Безгласна, Л. Мітіна, Н. Кузьміна та ін.

Питанням волонтерської діяльності приділяли значну увагу такі дослідники: А. Капська, О. Любарська, В. Назарук, В. Петрович, Ю. Поліщук (визначено принципи волонтерської роботи); І. Звєрєва, Г. Лактіонова, С. Савченко, С. Харченко (обгрунтовано роль волонтерства як складової соціально-педагогічної роботи 3 молоддю); О. Безпалько, Р. Вайнола, Н. Заверико, А. Капська (розкрито технології залучення та підготовки молоді до волонтерської діяльності); О. Кузьменко, Н. Романова, С. Толстоухова (визначено особливості роботи волонтерів у центрах соціальних служб для сім'ї, дітей та молоді); Ю. Поліщук (обгрунтовано волонтерство як складову соціально-педагогічної діяльності молодіжних організацій); Т. Лях, Л. Міщенко, К. Потопа, С. Фаворов (подано класифікацію 
волонтерських груп, зміст та напрями роботи волонтерів, аналіз особливостей соціальнопедагогічної діяльності студентських волонтерських груп); Н. Романова, Н. Трубнікова, Н. Черепанова (визначено мотиваційні чинники участі у волонтерській діяльності).

У роботах І. Литвиненко, М. Товкало, Т. Лях знаходимо детальну характеристику процесу формування особистості майбутнього педагога засобами волонтерства діяльності. Розкрито зміст та засадничі положення організації волонтерської діяльності як ефективного напряму підготовки вчителів у дослідженнях Т. Алєксєєнко, 3. Бондаренко, А. Данилової, Т. Куниці, А. Конончук та інших.

Отже, окремі положення презентованої проблеми досліджені та описані провідними вченими у різноманітних наукових доробках та публікаціях, однак, відсутній комплексний розгляд питання визначення ролі волонтерства у формуванні особистості майбутніх вчителів початкової школи.

У контексті вищезазначеного метою статті $\epsilon$ обгрунтування ролі волонтерської діяльності у формуванні особистості майбутнього вчителя початкової школи.

Виклад основного матеріалу дослідження. Сучасність формує перед учителем низку вимог до професійно значущих особистісних якостей, які характеризують інтелектуальну й професійну сторони особистості педагогів, здійснюють вплив на результат їхньої діяльності і розкривають індивідуальний стиль кожного педагога. Проведений аналіз нормативноправових актів 3 питань освіти (Закони України «Про освіту» (2017), «Про вищу освіту» (2020), Концепція «Нова українська школа» (2016), професійний стандарт «Вчитель початкових класів закладу середньої освіти» (2018) та інших) дав змогу виокремити вимоги до вчителя Нової української школи: високі моральні якості, відповідна педагогічна освіта, належний рівень професійної підготовки, фізичний та психічний стан здоров'я, що дозволяє виконувати професійні обов'язки в закладах загальної середньої освіти.

У типовій освітній програмі для підвищення кваліфікації педагогічних працівників визначені головні індивідуально-особистісні та професійно-діяльнісні якості педагога, набуття яких уможливить успішну реалізацію стратегічної мети та завдань реформування сучасної початкової школи. У програмі виокремлені компетентності, які відповідають вимогам Концепції «Нова українська школа», а саме: професійно-педагогічна, соціальногромадянська, загальнокультурна, мовно-комунікативна, підприємницька та інформаційноцифрова (2018).

Водночас, професійна компетентність учителя початкових класів - це не лише оволодіння знаннями, уміннями та досвідом з виконання професійних функцій, але й уміння самореалізовуватися в пізнавальній діяльності, чітко, логічно і доступно доносити свої думки до учнів та забезпечувати організацію співпраці у вирішенні освітніх завдань, знаходження шляхів спілкування, уміння розкрити творчий потенціал учнів та розвивати їх мислення.

Зазначене вище актуалізує необхідність пошуку та впровадження нових дисциплін, форм, методів, технологій, видів діяльності, котрі сприяли б становленню професійно важливих знань, умінь та особистісних якостей 3 огляду на зміст Концепції «Нова українська школа». Як засвідчує практика, саме волонтерська діяльність $є$ одним із напрямів діяльності закладів вищої освіти і значною мірою сприяє вирішенню окреслених вище завдань.

У сучасній мультимовній універсальній інтернет-енциклопедії «Вікіпедія» вказується, що «Волонтерська діяльність - індивідуальна чи колективна - це спосіб підтримки, піклування, надання допомоги членам громади; взаємодії між людьми для спільного 
вироблення нових шляхів вирішення проблем, які виникають. Це створює можливості для навчання та розвитку впродовж життя кожної людини» (2020).

Мета волонтерської діяльності - об'єднання та мобілізація добровільних зусиль небайдужих членів суспільства задля позитивних змін у суспільстві, місті, селі, а також спільного розв'язання загальних завдань та актуальних проблем (Алєксєєнко та Данілова, 2015 , c. 20).

На сучасному етапі нормативно-правові засади волонтерської діяльності, в тому числі в закладах вищої освіти, задекларовані у Законах України «Про освіту» (2017), «Про вищу освіту» (2020), «Про волонтерську діяльність» (2018) та інших.

Зокрема, у Законі України «Про волонтерську діяльність» зазначається, що «Волонтер це фізична особа, яка добровільно здійснює благодійну, неприбуткову та вмотивовану діяльність, що має суспільно корисний характер» (2018). Отже, «волонтер» - людина, яка вільно, самостійно, без примусу, безкорисливо займається діяльністю задля суспільства; добровільно надає безоплатні соціальні послуги та допомогу соціальним групам різного віку: особам із особливими потребами, дітям-сиротам, хворим, неблагополучним сім'ям, особам, які опинилися у складних життєвих ситуаціях тощо.

Волонтерська діяльність у закладі вищої освіти сприяє професійному становленню студентів, їх саморозвитку та самореалізації, дає можливість засвоювати соціальний досвід та виступає одним із напрямів позааудиторної роботи і $є$ потужним чинником формування ціннісних орієнтацій молоді.

Здійснений аналіз наукових джерел та публікацій уможливив визначення важливих ознак волонтерства, які є актуальними для студентів педагогічного факультету:

1. Турбота про людей (дітей та дорослих), природу. Можливість співчувати, допомагати та піклуватися про інших людей сприяє становленню атмосфери взаємопідтримки та взаємодовіри. При цьому у майбутніх педагогів формуються моральні почуття, переконання, бажання допомагати тим, хто цього потребує. Для сучасного українського суспільства це створює міцний соціально-педагогічний ресурс, так зване оптимальне соціальне середовище для співіснування людей і довкілля.

2. Гуманність, людяність, толерантність у відносинах між усіма учасниками освітнього процесу. Ця ознака доводить необхідність введення волонтерської діяльності у зміст підготовки майбутніх вчителів початкової школи, оскільки створює умови для запровадження особистісно орієнтованого підходу та педагогіки партнерства в закладах освіти. Налагодження партнерських зв'язків між вчителями, батьками та учнями є однією 3 головних умов створення Нової української школи. Крім того, адекватне толерантне ставлення до усіх учнів, у тому числі й з особливими освітніми потребами, створює оптимальні умови для ефективної реалізації засад інклюзивної освіти. Важливим є те, що волонтерська діяльність здійснюється без дискримінації за статтю, віросповіданням, національністю, інтересами, що дає змогу сформувати у майбутніх вчителів початкової школи толерантне ставлення до всіх учасників освітнього процесу.

3. Духовність $i$ громадянськість. Ця ознака передбачає здійснення ефективного позитивного впливу благодійної діяльності на формування духовності студентів педагогічного факультету, їх цілеспрямованості, відповідальності, активної громадянської позиції, взаємодовіри та позитивно спрямованої поведінки.

4. Джерело досвіду спілкування. Під час налагодження соціальної взаємодії 3 представниками різних соціальних груп та вікових категорій, вирішення конфліктних ситуацій, лобіювання особистісних та суспільних інтересів створюються необхідні умови 
для формування і вдосконалення комунікативних навичок та вмінь. Зазначене вище $є$ необхідним для майбутнього вчителя початкової школи.

5. Ініціативність, креативність. У процесі здійснення благодійної діяльності волонтери часто створюють нові програми, ефективні форми, методи, засоби, виступаючи при цьому ініціаторами та генераторами нових ідей та досвіду.

6. Етичні норми. Це одна з важливих ознак волонтерства, яка характеризує суспільні взаємовідносини і підтримується на свідомому рівні. У студентів відбувається становлення поведінкових умінь, у тому числі й вирішувати конфліктні ситуації, що $є$ важливими для ефективної професійної підготовки. Крім того, майбутні вчителі знайомляться на практиці з різними соціальними верствами населення, способами та шляхами надання їм допомоги. I завдяки участі у різноманітних благодійних заходах, акціях у студентів формуються практичні вміння та навички.

Розглянемо роль волонтерської діяльності у формуванні особистості майбутнього вчителя початкової школи на прикладі діяльності волонтерського центру «Від серця до серця», який функціонує при кафедрі теорії і методики виховання РДГУ і є структурним підрозділом Регіонального комплексного науково-методичного центру інноваційних технологій освітнього процесу. Нині центр об’єднує 51 здобувача вищої освіти педагогічного факультету різних курсів.

Головною метою діяльності центру є залучення студентської молоді до соціально орієнтованої та краєзнавчо-пошукової діяльності, виховання духовно-моральних якостей (доброта, милосердя, людяність, відповідальність, ініціативність); виховання здатності до емпатії, толерантності та альтруїзму; формування соціально активної, громадянської та моральної позиції особистості (Стельмашук, 2018).

Отже, актуальним постає процес становлення професійної компетентності майбутніх педагогів 3 питань морального виховання. Важливою умовою при цьому виступає сформованість моральної зрілості вчителя, яка передбачає наявність готовності реалізовувати моральні норми і цінності у конкретних діях (Гринькова, 2016).

Аналіз досвіду діяльності студентського волонтерського центру «Від серця до серця» засвідчив значний потенціал волонтерської діяльності як одного із шляхів формування особистості майбутніх вчителів початкової школи, оскільки уможливлює прояв не лише професійних, а й індивідуальних та особистісних якостей студента. Серед основних форм діяльності волонтерського центру: тренінги, благодійні акції, ярмарки, дискусій, майстеркласи, квести, флешмоби, екскурсії, подорожі, ігри, благодійні акції та ін.

Наприклад, програмою «Нова українська школа» у поступі до цінностей» визначені базові моральні цінності, які повинні стати провідними орієнтирами в освітній діяльності майбутнього вчителя початкової школи, це такі як: любов, повага до інших, гідність, відповідальність, совість, свобода, толерантність, справедливість, рівноправ'я, ініціативність (2018). Здобувачі освіти, залучаючись до благодійних акцій та ярмарків, проєктів тощо, мають змогу на практиці, окрім закріплення академічних знань, умінь та навичок, набутих упродовж освоєння навчальних дисциплін, виховувати у собі ці цінності.

Важливою вимогою сьогодення $є$ наявність у кожного учасника освітнього процесу, зокрема й у майбутнього вчителя початкової школи, так званих «м'яких навичок» (softskills), які передбачають уміння критично мислити, працювати в команді, вирішувати проблеми, ефективно спілкуватися, бути цілеспрямованими та креативними. Одним із шляхів формування softskills $\epsilon$ використання інтерактивних методів організації освітнього процесу в сучасному закладі освіти. Підготовка волонтерських заходів повною мірою передбачає використання активних методів і форм залучення студентів до практичної діяльності. 
Значний потенціал має волонтерська діяльність i для розвитку соціальної компетентності майбутніх учителів початкової школи. Так, організовуючи та здійснюючи благодійні акції (новорічно-різдвяна акція «Подаруй дітям радість», «Великодній кошик» тощо), реалізуючи проєкти, зокрема, участь у створенні дитячого майданчика, проведення костюмованого дійства, ігор та розваг для вихованців Рівненського обласного спеціалізованого будинку дитини, майбутні педагоги не лише удосконалюють педагогічну майстерність, а й набувають важливих i необхідних соціальних навичок (навичок взаєморозуміння, співпраці; поваги одне до одного, толерантного ставлення, емпатії; уміння працювати в групах та нести відповідальність за свою діяльність тощо).

Участь у волонтерській діяльності сприяє розвитку лідерських якостей, творчого потенціалу, критичного мислення майбутніх педагогів та мотивації до самореалізації в особистісному та соціальному планах, а також вироблення активної громадянської позиції, усвідомлення взаємозв'язку між індивідуальною свободою, правами людини та іiі соціальною відповідальністю.

Сьогодні в оновлених нормативно-правових актах $з$ питань освіти зазначено, що певний рівень розумового розвитку не завжди є запорукою досягнення успіхів у професійній діяльності. Як засвідчує досвід, найбільшого успіху досягають ті люди, які здатні керувати власними емоціями та поведінкою, проявляють високий рівень стресостійкості та вміють швидко й адекватно реагувати у критичних ситуаціях. Саме цими якостями повинен володіти педагог. Вчитель, який не вміє правильно реагувати на події, що відбуваються, керувати власними емоціями, не готовий долати труднощі, викликані швидкоплинними обставинами, не може забезпечити безпечне освітнє середовище, передбачене Концепцією «Нова українська школа» (2016).

Саме волонтерська діяльність сприяє розвитку емоційного інтелекту як наскрізного вміння у Новій українській школі, адже майбутні педагоги, спілкуючись із соціально вразливими категоріями (дітьми-сиротами, людьми з обмеженими можливостями тощо), розвивають здатність адекватно сприймати, оцінювати, виражати та регулювати емоції, розуміти емоції інших, що є важливим для створення сприятливого освітнього середовища.

Отже, волонтерська діяльність $є$ невичерпним додатковим позанавчальним ресурсом, який сприяє вирішенню таких завдань: розвиток професіоналізму особистості студентів, поглиблення інтересу до обраної професії, формування почуття професійної відповідальності, набуття практичного досвіду співпереживання та його рефлексія, становлення досвіду формування цінностей, свідоме якісне визначення своєї майбутньої сфери професійної діяльності, спираючись на свою індивідуальність; розвиток комунікативних здібностей, формування вміння вести конструктивний діалог з різними за віком та соціальним статусом людьми; усвідомлення соціальної значущості професії, потреби підвищувати персональну пізнавальну активність, прагнення формувати якості, практичний досвід, необхідні для подальшої роботи; формування психологічної готовності до самостійної практичної роботи після закінчення закладу вищої освіти (Литвиненко, 2013, c. 190).

Оптимальне поєднання благодійної діяльності у позааудиторний i навчальний час (лекції, практичні, семінарські заняття та ін.), переконана І. Литвиненко, значно підвищують якість професійної підготовки майбутніх педагогів (2013, с. 193).

Висновки і перспективи подальших розвідок. Отже, волонтерська діяльність відіграє особливе важливе значення для підготовки майбутнього вчителя початкової школи, є одним iз ефективних сучасних видів залучення молоді до лобіювання суспільних інтересів, громадянських прав і свобод, соціальних чеснот, завдяки чому створюються умови для 
прояву вмінь допомогти тим, хто цього потребує, відтак, для саморозвитку, самовдосконалення. Перспективами подальших наукових розвідок $\epsilon$ розробка перспективних шляхів вдосконалення волонтерської діяльності в закладах вищої та загальної середньої освіти, а також технологія підготовки майбутніх вчителів до професійної діяльності засобами волонтерства в Новій українській школі.

\section{СПИСОК ВИКОРИСТАНИХ ДЖЕРЕЛ}

Міністерство освіти і науки України (2020). Закон України «Про вищу освіту» URL: https://zakon.rada.gov.ua/laws/show/1556-18 [Дата звернення 01 травня 2020].

Інститут проблем виховання, Інститут модернізації змісту освіти (2018). Програма «Нова украӥнська школа» у поступі до ијнностей. Київ. 40 с.

Міністерство освіти і науки України (2017). Закон України «Про освіту» URL: https://zakon.rada.gov.ua/laws/show/2145-19 [Дата звернення 02 травня 2020].

Міністерство освіти і науки України (2018). Типова освітня програма для підвищення кваліфікації педагогічних працівників. URL: https://mon.gov.ua/ua/npa/pro-zatverdzhennyatipovoyi-osvitnoyi-programi-organizaciyi [Дата звернення 29 квітня 2020].

Сучасна мультимовна універсальна інтернет-енциклопедія (2017). Волонтерство. URL: https://uk.wikipedia.org/wiki [Дата звернення 20 квітня 2020].

Алєксєєнко, Т., Данілова, А., Конончук, А., Куниця, Т. (2015). Доброчинна діяльність школярів: Методичні рекомендації. Ніжин: Видавець ПП Лисенко М. 104 с.

Леонова В. (2019). Волонтерський рух в Україні: Методичні рекомендації. Одеса: видавець Букаєв В. 56 с.

Міністерство освіти і науки України (2018). Закон України «Про волонтерську діяльність»/ URL: https://zakon.rada.gov.ua/laws/show/3236-17 [Дата звернення 3 травня 2020].

Стельмашук, Ж. (2018). Положення про волонтерський Центр «Від серия до серияя. Рівне: Рівненський державний гуманітарний університет. 17 с.

Гринькова, Н. (2016). Теоретико-методичні засади формування професійної компетентності педагогів 3 питань морального виховання молодших школярів в умовах позашкільного навчального закладу. Інноватика у вихованні. 6, с. 84-91.

Литвиненко, І. (2013). Роль волонтерства у професіоналізації особистості студентівпсихологів в умовах ВНЗ. Науковий вісник Миколаївського національного університету імені В. О. Сухомлинського, 2 (10), с. 191-195.

\section{REFERENCES}

Ministry of Education and Science of Ukraine. (2020). Zakon Ukrayini «Pro vyshchu osvitu» [Law of Ukraine "On higher education"].URL: https://zakon.rada.gov.ua/laws/show/1556-18 [Data zvernennia 1 travnia 2020]. (in Ukrainian)

Institute of problems of education, Institute of modernisation of maintenance of education (2018). Prohrama Nova ukrainska shkola u postupi do tsinnostei [Program New Ukrainian School in Moving Toward Values]. Kyiv. (in Ukrainian)

Ministry of Education and Science of Ukraine. (2017). Zakon Ukrayini «Pro osvitu» [Law of Ukraine "On Education”]. URL: https://zakon.rada.gov.ua/laws/show/2145-19 [Data zvernennia 2 travnia 2020]. (in Ukrainian)

Ministry of Education and Science of Ukraine. (2018). Typova osvitnia prohrama dlia pidvyshchennia kvalifikatsii pedahohichnykh pratsivnykiv [Typical Educational Program for Professional Development of Teachers]. URL: https://mon.gov.ua/ua/npa/pro-zatverdzhennyatipovoyi-osvitnoyi-programi-organizaciyi [Data zvernennia 29 kvitnia 2020]. (in Ukrainian) 
Suchasna multymovna universalna internet-entsyklopediia.(2017). Volonterstvo [Volunteering]. URL: https://uk.wikipedia.org/wiki [Data zvernennia 20 kvitnia 2020]. (in Ukrainian)

Alieksieienko, T., Danilova, A., Kononchuk, A. \& Kunytsia, T. (2015). Dobrochynna diialnist shkoliariv [Charitable Activity of Schoolchildren: Methodical Recommendations]. Nizhyn: ydavets PP Lysenko M. (in Ukrainian)

Leonova, V. (2019).Volonterskyi rukh v Ukraini [Volunteer Motion in Ukraine]. Odesa: vydavets Bukaiev V. (in Ukrainian)

Ministry of Education and Science of Ukraine. (2018). Zakon Ukrainy "Pro volontersku diialnist" [Law of Ukraine "On Volunteer Activity"]. URL: https://zakon.rada.gov.ua/laws/show/3236-17 [Data ostanoho zvernennia 3 travnia 2020]. (in Ukrainian)

Stelmashuk, Zh. (2018). Polozhennia pro volonterskyi Tsentr "Vid sertsia do sertsia" [Regulations on the Volunteer Center "From Heart to Heart"]. Rivne: Rivnenskyi derzhavnyi humanitarnyi universytet. (in Ukrainian)

Hrynkova, N. (2016). Teoretyko-metodychni zasady formuvannia profesiinoi kompetentnosti pedahohiv z pytan moralnoho vykhovannia molodshykh shkoliariv $\mathrm{v}$ umovakh pozashkilnoho navchalnoho zakladu [Theoretical and Methodical Bases of shaping Professional Competence of Teachers Concerning Moral Education of elementary schoolchildren in the Context of Out-ofschool Educational Institution]. Innovatyka u vykhovanni, 6, s.84-91. (in Ukrainian)

Lytvynenko, I. (2013). Rol volonterstva u profesionalizatsii osobystosti studentiv-psykholohiv v umovakh VNZ [A Role of Volunteering in the Professionalization of Personality of Studentspsychologists in Higher education]. Naukovyi visnyk Mykolaivskoho derzhavnoho universytetu imeni V. O. Sukhomlynskoho, 2(10), 191-195. (in Ukrainian)

\title{
THE ROLE OF VOLUNTEER ACTIVITY IN THE DEVELOPMENT OF FUTURE ELEMENTARY SCHOOL TEACHER
}

\author{
Nadiia Hrynkova \\ Candidate of Pedagogical Sciences, Associate Professor, \\ Associate Professor at the Department of Theory \\ And Methods of Education,f \\ Rivne State University for the Humanities, \\ Rivne, Ukraine \\ ORCID: 0000-0002-5774-8699, \\ e-mail: nadiia.hrynkova@rshu.edu.ua \\ Zhanna Stelmashuk \\ Candidate of Pedagogical Sciences, \\ Associate Professor at the Department of Theory \\ and Methods of Education, \\ Rivne State University for the Humanities, \\ Rivne, Ukraine \\ ORCID : 0000-0003-2368-4209, \\ e-mail: zhanna.stelmashuk@rshu.edu.ua
}




\title{
AlinaVakoliuk \\ Candidate of Pedagogical Sciences, Associate Professor at the Department of Theory and Methods of Education, Rivne State University for the Humanities, \\ Rivne, Ukraine \\ ORCID: 0000-0003-1545-0867, e-mail: alinavakoliuk88@gmail.com
}

\begin{abstract}
The article substantiates the role of volunteer activity in the formation of the personality of the future elementary school teacher. The analysis of normative-legal documents on education made it possible to state that a teacher should be a person with high moral qualities, with appropriate pedagogical education, proper level of vocational training, ensuring the efficiency and quality of his/her work, with good physical and mental health, and allows to perform professional duties effectively. Volunteering is a way to support, care for, and help those who are in need.

The characteristics of volunteering that are important for students of the Faculty of Education have been identified: caring for people (children and adults), nature; humanity, tolerance in relations between all participants of the educational process; spirituality and citizenship; source of communication experience; initiative, creativity; ethical standards. The experience of the student volunteer center "From heart to heart" has been characterized, which testified to the significant potential of volunteer activity as one of the factors shaping the personality of the future teacher of the New Ukrainian School.

It was practically proved that charitable activity has a significant potential for the development of basic moral values of personality, social competence of students of the Faculty of Education (skills of mutual understanding, cooperation, respect, tolerance, empathy, responsibility, ability to work in groups); promotes the development of leadership skills, creativity, critical thinking; contributes to the improvement of pedagogical skills, development of stress resistance and emotional intelligence of future elementary school teachers. This was facilitated by the use of the system of appropriate forms of activity of the volunteer center: trainings, charity events, fairs, discussions, workshops, quests, flash mobs, excursions, trips, games, charity events etc. It was established that volunteering is one of the main areas of activities of higher education institutions and is of great importance for the training of future elementary school teacher, his/her development, self-development and self-improvement.

Keywords: volunteering, volunteer work, charity, personality of a future elementary school teacher, professional competence, New Ukrainian School, student volunteer center «From heart to heart».
\end{abstract}

Стаття надійшла до редакиї 07. 05. 2020 р. 